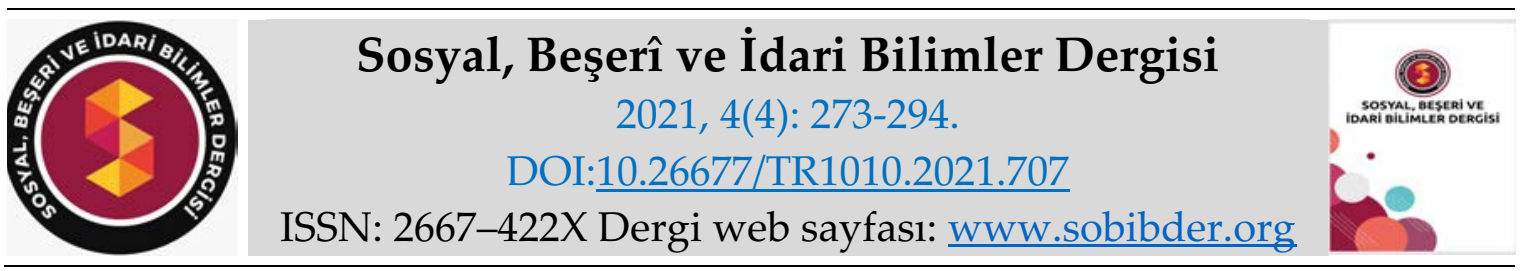

ARAȘTIRMA MAKALESI

\title{
Toplumsal Cinsiyet Rolleri ve Erkeklere Yönelik Düşmanca Tutumların Pornografiye Yönelik Tutumlar Üzerindeki Etkileri
}

Arş. Gör. Ogeday ÇOKER, Pamukkale Üniversitesi, Fen-Edebiyat Fakültesi, Psikoloji Bölümü, Denizli, e-posta: ocoker@pau.edu.tr

ORCID: https://orcid.org/0000-0002-7757-4542

Prof. Dr. Sevim CESUR, İstanbul Üniversitesi, Edebiyat Fakültesi, Psikoloji Bölümü, İstanbul, eposta: sevimcesur@yahoo.com

ORCID: https://orcid.org/0000-0002-4038-0592

Öz

Araştırmada; pornografiye yönelik tutumlar ile toplumsal cinsiyet rollerine yönelik tutumlar ve erkeklere ilişkin düşmanca tutumlar arasındaki ilişkiler incelenmiştir. Katılımcılar, internet üzerinden ulaşılan 400'ü kadın 271'i erkek toplam 671 kişiden oluşmaktadır. Pornografiye ilişkin tutumların ölçülmesinde Pornografiye Yönelik Tutum Ölçeği, toplumsal cinsiyetlere rollerine ilişkin tutumların ölçümünde Toplumsal Cinsiyet Rolleri Tutum Ölçeği ve erkeklere ilişkin düşmanca tutumları ölçmek amacıyla Erkeklere İlişkin Çelişik Duygular Ölçeği'nin Erkeklere İlişkin Düşmanca Tutumlar alt ölçeği kullanılmıştır. Uygulanan bağımsız örneklemler t-testi bulgularına göre erkeklerin pornografiye yönelik tutumları kadınlara göre daha olumludur. Toplumsal cinsiyet rollerine yönelik tutumlar ile pornografiye yönelik tutumlar arasında pozitif yönlü anlamlı bir ilişki bulunmuştur. Yapılan biçimlendirici regresyon analizlerinde toplumsal cinsiyet rollerine ilişkin tutumlar ile pornografiye yönelik tutumlar arasındaki ilişkide cinsiyetin biçimlendirici bir etkisine ulaşılamazken erkeklere yönelik düşmanca tutumların hem kadın hem erkek katılımcılar için biçimlendirici bir etkisi olduğu görülmüştür. Bulgular, içerisinde olduğu düşünülen cinsiyetçi şiddetin pornografiye yönelik tutumları farklı düzeylerde etkilediği şeklinde yorumlanmıştır.

Anahtar Kelimeler: Pornografi, Toplumsal Cinsiyet Rolleri, Feminizm, Çelişik Duygulu Cinsiyetçilik, Erkeklere İlişkin Düşmanca Tutumlar.

Makale Gönderme Tarihi: 16.09 .2020

Makale Kabul Tarihi: 01.04 .2021

\section{Önerilen Atıf:}

Çoker, O. ve Cesur, S. (2021). Toplumsal Cinsiyet Rolleri ve Erkeklere Yönelik Düşmanca Tutumların Pornografiye Yönelik Tutumlar Üzerindeki Etkileri, Sosyal, Beşeri ve İdari Bilimler Dergisi, 4(4): 273-294.

(c) 2021 Sosyal, Beşerî ve İdari Bilimler Dergisi. 


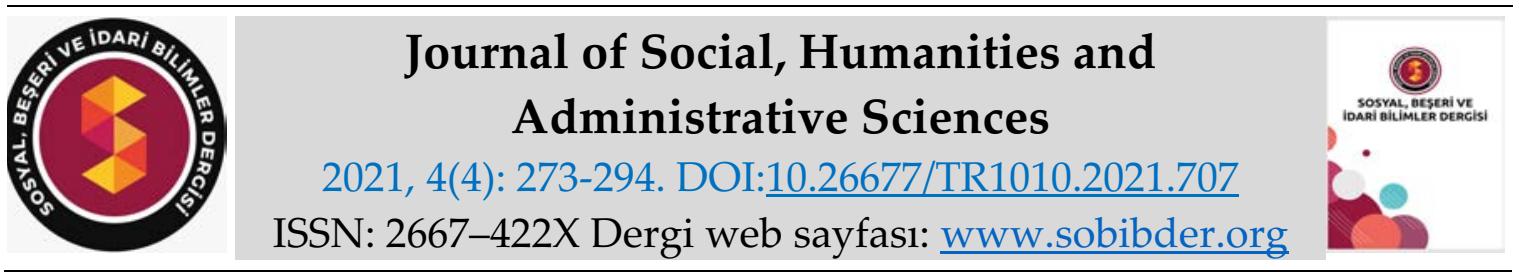

RESEARCH PAPER

\title{
Effects of Gender Roles and Hostility toward Men on Attitudes toward Pornography
}

Research Assistant Ogeday ÇOKER, Pamukkale University, Faculty of Arts and Sciences, Denizli, e-mail: ocoker@pau.edu.tr ORCID: https://orcid.org/0000-0002-7757-4542

Prof. Dr. Sevim CESUR, İstanbul University, Faculty of Literature, İstanbul, e-mail: sevimcesur@yahoo.com

ORCID: https://orcid.org/0000-0002-4038-0592

\begin{abstract}
This research analyzes attitudes towards pornography on the basis of the perception of individuals for gender roles and attitudes of hostility towards men. 671 participants, 400 women and 271 men participated in the study by the web. Attitudes toward Pornography Scale were used to measure attitudes towards pornography, Gender Roles Attitude Scale was used to measure attitudes towards gender roles. The Hostility toward Men subscale of Ambivalence toward Men Inventory were used to measure attitudes hostility toward men. According to independent samples t-test findings, mens attitudes towards pornography were more positive than womens. Gender role attitudes and attitudes toward pornography were found to be significantly correlated. In the moderated regression analyzes, it was found that sex has no moderate effects on gender role attitudes and attitudes toward pornography. Hostility toward men has moderate effects on the relation between gender role attitudes and attitudes toward pornography for both women and men. Findings are interpreted as sexist violence, which is thought to be involved, affects attitudes towards pornography at different levels.
\end{abstract}

Keywords: Pornography, Gender Roles, Feminism, Ambivalent Sexism, Hostility Toward Men. Received: 16.09 .2020

Accepted: 01.04.2021

\section{Suggested Citation:}

Çoker, O. and Cesur, S. (2021). Effects of Gender Roles and Hostility toward Men on Attitudes toward Pornography, Journal of Social, Humanities and Administrative Sciences, 4(4): 273-294.

(c) 2021 Sosyal, Beşerî ve İdari Bilimler Dergisi. 


\section{Gíriş}

Sansür, bireysel özgürlüklerin devlet tarafından sınırlanabilmesi ve internet yasakları çerçevesinde sıkça gündem olan pornografi Türkiye'de bireylerin günlük hayatlarında oldukça fazla yer alan bir kavramdır. Bilgi Teknolojileri ve İletişim Kurumu'nun 2012 raporuna göre Türkiye'de dakikada iki milyon kişi internet üzerinden porno izlemektedir. Ayrıca ilgili rapora göre Türkiye, dünyada porno izleyen ülkeler arasında dördüncü sırada bulunmaktadır. Dolayısıyla günlük hayat içerisinde, kamusal alanda sıkça konuşmadığımız bir konunun hayatımızın büyük bir bölümünü kapladığını söylememiz mümkündür. Ancak Türkiye psikoloji literatüründe hayatımızda bu denli yer kaplayan bir kavram olan pornografiye yönelik tutumları ele alan bir çalışma bulunmamaktadır.

Bu çalışmanın amacı pornografiye yönelik tutumlar açısından cinsiyet grupları arasında bir fark olup olmadığını incelemektir. Bazı feminist kuramcıların, pornografinin öncelikle erkekler için üretilen bir materyal olduğu ve içerisinde cinsiyetçi bir şiddet barındırdığı argümanından yola çıarak, erkeklere ilişkin düşmanca tutumların pornografiye yönelik tutumlar üzerinde etkisinin olup olmadığını ele almak araştırmanın bir diğer amacıdır.

\section{FEMINIST KURAMLAR ve PORNOGRAFI}

$\mathrm{Bu}$ araştırma, pornografinin cinsiyet temelli yönünü referans almış olduğu için söz konusu kavramın üzerinde özellikle duran feminist kuramları incelemek gerekmektedir. Pornografiye genel itibariyle olumlu ve olumsuz olmak üzere iki uçtan yaklaşan feminist kuramlar, temel ayrımlarını pornografinin erotizm ile olan farkından yola çıarak kurgulamışlardır. Mackinnon ve Dworkin (1997), pornografi ve erotizm arasındaki farkın pornografinin içerdiği cinsiyetçi şiddetten kaynaklandığını iddia etmektedir. Hatta feminist kuramcılar bu noktadan yola çıkarak erotizmi de kadın kimliğinin güçlü bir ayağı olarak sunmaktadırlar. Cinsellik erkekler için olduğu kadar kadınlar için de var olan bir kavramdır, bu sebeple de kadının cinsel gücünü öne çıaran bir erotizm, cinsiyet eşitliğinde önemli bir basamak olarak ele alınmaktadır (Watson, 2007). Erotizm hem pornografi karşıtı olan hem de pornografiyi destekleyen feminist gruplar için olumlu bir kavram gibi görünürken pornografi kavramı ortaya "seks savaşları"nı çıkarmıştır. Seks savaşları, pornografiye yönelik olumsuz bakışa sahip feminist kuramcılar ile pornografiyi kadınlar için olumlu bir kavram olarak ele alan feminist kuramcılar arasında geçen ve 70'lerin sonlarından başlayıp 80'lerin başlarına kadar süren bir çekişme dönemidir. Seks savaşları olarak adlandırılan bu iki uçlu çekişmenin, feminist hareketin Kuzey Amerika'daki konumuna büyük bir zarar verdiği iddia edilmektedir. Feminist kuramcılar arasındaki bu karşıtlığın bir ucu pornografiyi desteklemenin kadınlara yönelik zulmün de desteklendiği anlamına geldiğini savunurken diğer bir ucu ise pornografi karşıtlığını ahlak bekçiliği ile bir tutmuşlardır (Purcell, 2012).

Pornografinin kadını aşağıladığını ve kadının toplumdaki konumunu olumsuz etkilediğini belirten pornografi karşıtı feministlerden MacKinnon ve Dworkin (1997) pornografinin aslında inşa etmekte olduğu cinsiyet eşitsizliğini, doğal bir cinsiyet farkı gibi sunarak görünmez kıldığını belirtirler. Oysa bu araştırmacılara göre ezilen ve cinsel şiddet gören kadın figürü cinsiyet farklılıklarının sonucu değil tam olarak cinsiyet ayrımcılığının bir sonucudur. MacKinnon (1987) pornografinin içerdiği cinsel kötüye kullanım ve şiddet çeşitliliği ile günlük hayatta kadınların istekleri dışında cinsel ilişkiye girmeleri arasında bir bağ olduğunu belirtir. Pornografik materyallerin kadınlara karşı kötü muamele içerdiğini belirten MacKinnon bunu izleyen erkeklerin birlikte oldukları kadınları cinsel ilişkiye girmeye zorlayan, kadınları suistimal eden erkekler olduğuna vurgu yapar. Dolayısıyla pornografi, bu feminist yazara göre toplumdaki 
kadın ve erkek eşitsizliğinin en net yansımalarından biridir. Bart (1985) ve Diamond (1980) gibi pornografi karşıtı başka isimler de pornografideki kadın figürüne yüklenen anlamın, erkeklerin kadınları daha değersiz olarak algılamalarına, onlara ikinci sınıf bir konum atfetmelerine neden olduğunu belirtmektedirler. Erkeklerin pornografide farklı rollerde bulunabildiklerine, buna karşıllk kadınların ise sadece bir seks objesi rolüne indirgendiğine işaret etmektedirler. Hatta bu seks objeleri sıklıkla şiddet içeren seksüel davranışların da nesnesi olmaktadırlar. Pornografideki bu durum toplumda, erkek ve kadından beklenen farklı cinsiyet rollerinin eşitsizliğini de yansıtmaktadır. Pornografiye yönelik daha 1lımlı bir tutuma sahip olan McCormack (1993) ise pornografi karşıtı feministlerin kadın kimliği üzerinden yürüttükleri tartışmayı desteklemektedir ve pornografinin içeriğindeki şiddetin önemli olduğuna, ancak toplumun diğer alanlarında kadınlara gösterilen şiddet türlerinden zararları bakımından farkı olmadığına vurgu yapmaktadır. McCormack'e göre pornografinin asıl zararı kadının şehvet düşkünü olarak çizilmesi değil tersine geleneksel toplumsal cinsiyet rolleri ile çizilmesidir. Bu durum kadın kimliğinin geleneksel sınırların içerisine sıkışmasına sebep olmaktadır. Oysa McCormack'e göre kadının pornografide geleneksel değil de şehvetli bir özne şeklinde sunulması, toplumda cinselliğiyle barışan kadının temsilidir. Şehvet düşkünü kadın kimliğiyle sağlanacak cinsiyet eşitliğinin ancak kendisi gibi şehvet düşkünü erkek figürünün de temsiliyle gerçekleşebileceğini de hatırlatan McCormack aksi takdirde cinsel isteklerini arabaya, politikaya, paraya vs. yönelten bir "iş adamı" gibi sunulan güçlü erkek figürlerinin karşısında sadece "şehvet düşkünü" bir kadın kimliğinin bulunmasının, erkeği her koşulda aşırı değerli bir hale getirirken kadının tek yönlü bir figür olarak görülmesine sebep olacağını da hatırlatır. Bu yüzden pornografideki iki cinsiyet grubu üyelerinin de eşit rollere sahip olması gerekmektedir. Ayrıca sağlanması gereken bu eşitliğin, pornografiye getirilecek sansür ve rol kısıtlamalarıyla gerçekleştirilmemesi gerektiğini belirten McCormack, böyle bir sınırlama ve sansürün kadını "korunmaya muhtaç" bir konuma getirdiğini ve kadının toplumdaki gücüne darbe vurduğunu belirtir.

Pornografi karşıtı feministlere karşıt bir görüş olarak ortaya çıkan sex-pozitif feministlerin temel dayanak noktası ise kadın cinselliğinin kadını özgürleştireceği argümanıdır. Bright ve Rubin (1995, 1993, akt. Purcell, 2012) gibi bu akımın öncüsü feministler pornografi karşıtı feministleri çok yüzeysel bir pornografi-şiddet ilişkisi kurmakla eleştirmekte ve pornografinin ancak izleyicisinin ona yüklediği öznel anlam ile kötülenebileceğini belirtmektedirler. Pornografinin cinsiyetçiliği doğurmadığını, toplumda hâlihazırda var olan cinsiyetçiliğin, bireylerin öznel yaşantılarıyla pornografi içerisinde anlam bulabildiğine işaret eden feminist kuramcılara göre pornografi kötü olmak zorunda değildir, toplumdaki cinsiyetçiliği içselleştirmiş bireylerin pornografiden çıkardıkları anlam kötü olabilir. Bu yüzden pornografiyi toplumda hali hazırda var olan cinsiyet eşitsizliğinin bir sebebi gibi sunmanın aslında toplumdaki gerçek cinsiyetçi şiddetin göz ardı edilmesine yol açtı̆̆ını ve büyük bir sorunu küçük bir noktaya sıkıştırdığını belirmektedirler.

Butler (1997) ve Segal (1998) gibi sex-pozitif feministler pornografiye yönelik olumlu tavırlarını sadece pornografi karşıtı feministlere karşıt görüşlerinden değil kadının özgürleşmesindeki işlevinden de yola çıkarak oluşturmuşlardır. Pornografinin, cinselliği sadece erkeklerin haz aldığ cinsiyetçi bir kavramlaştırmadan kurtardığın belirtmektedirler. Hatta pornografik materyalde sunulan erkeklik tarifinin gerçek dünyadakiyle benzeşmemesi sebebiyle ataerkilliğin gücüne ilişkin karşıt bir duruşu içerdiğini, bu yüzden de pornografinin, cinsellikteki iktidar ilişkilerine yeni bir anlam yüklediğini savunmaktadırlar. Pornografideki hayali dünyanın güçlü erkeklik inşası ile toplumdaki başarısızlıklara uğrayan, yer yer güçsüz olan erkek figürünün çeliştiğine, gerçek erkek kimliğine atfedilen gücün bir yanılsamadan ötesi olmamasına vurgu yaptığına dikkat çekmişlerdir. Pornografi, izleyicilerine sürekli gerçek hayattaki ataerkilliğin güçsüzlüğünü hatırlatmaktadır. 
Görüldüğü üzere pornografi üzerine feminist isimler kuramlarını, pornografiyi iki zıt kutuptan alarak ortaya atmışlardır. Ancak ne yazık ki feminist kuramcılar pornografiye yönelik bu açıklamalarını görgül araştırmalar ile desteklememişlerdir. Kavrama ilişkin görgül çalışmalar daha çok kullanım sıklıkları (Carroll, Padilla-Walker, Nelson, Olson, Barry, ve Madsen, (2008); Diamond ve Dannemiller, 1989; Flood ve Hamilton, 2003; Frable, Johnson ve Kellman, 1997; Wallmyr ve Welin, 2006), pornografi tüketiminin sebepleri (Rogala ve Tydén, 2003; Wallmyr ve Welin, 2006), ortaya çıkardığı bireysel sonuçlar (Allen, Emmers, Gebhardt ve Giery, 1995; Amoah, 1997; Bridges ve Morokoff, 2011; O’Reilly, Knox ve Zusman, 2007; Poulsen, Busby ve Galovan, 2013; Schneider, 2000) ve basit tutum araştırmaları (Evans-DeCicco ve Cowan, 2001; Johansson ve Hammarén, 2007) üzerinden yürütülmüştür. Ancak tüm çalışmalar cinsiyet farklarını temel bir değişken olarak ele almışlar ve pornografinin cinsiyetler ile ilişkilenme biçimine farklı açılamalar getirmişlerdir. Bu yüzden pornografi tüketimi ve cinsiyet ilişkilerine değinen bu çalışmaların sonuçlarına, pornografiye yönelik tutumlar üzerinde cinsiyetler arası farkları incelemeyi amaçlayan bu çalışmada da kısaca değinilmesi gerekli görülmektedir.

\section{Pornografiye İlişkin Yapılan Görgül Çalışmalar}

Üzerine konuşmadığımız ancak hayatımız içerisinde kendisine bu kadar yoğun bir şekilde yer bulan pornografiye yönelik Türkiye'de sınırlı sayıda çalışma (Temelli, 2019) olmasına rağmen dünyada konuyu farklı biçimlerde ele alan çalışmalar bulunmaktadır (Allen, Emmers, Gebhardt ve Giery, 1995; Amoah, 1997; Bridges ve Morokoff, 2011; Carroll, Padilla-Walker, Nelson, Olson, Barry, ve Madsen, (2008); Diamond ve Dannemiller, 1989; Evans-DeCicco ve Cowan, 2001; Flood ve Hamilton, 2003; Frable, Johnson ve Kellman, 1997; O’Reilly, Knox ve Zusman, 2007; Rogala ve Tydén, 2003; Wallmyr ve Welin, 2006). Bu görgül çalışmalar; kullanım sıklıkları, tüketim sebepleri, pornografiye ve pornografi oyuncularına ilişkin tutumlar gibi farklı konular üzerine odaklanırken araştırmaların büyük kısmı bu konuları, cinsiyetler arası farklılaşma düzeylerine göre değerlendirmektedirler. Pornografinin, toplumdaki kadın-erkek kimlik ve rollerine yönelik daha önce bahsedilen feminist kuramlardaki tartışmaların önemli bir odağı olduğu düşünülünce bu durum oldukça anlaşılabilir gözükmektedir.

Yapılan ilk araştırmalar pornografik materyallerin tüketim sıklıklarını ele alan çalışmalardır. Kullanım sıklığının cinsiyetlere göre değişimi incelendiğinde erkeklerin kadınlara göre daha fazla pornografik materyali tükettikleri görülmektedir (Diamond ve Dannemiller, 1989; Flood ve Hamilton, 2003; Frable, Johnson ve Kellman, 1997; Wallmyr ve Welin, 2006). Araştırmacılar, tüketim sıklığının cinsiyetler arasında böyle bir fark göstermesinin pornografinin, pornografi karşıtı feministlerin belirttiği gibi, daha çok erkekler için üretilen bir materyal olduğu algısını da beslediğini belirtmektedirler. Bununla birlikte pornografik materyalin tüketiminin birçok farklı değer ile de ilişkili olduğunu gösteren çalışmalar mevcuttur. Dini temelli değer inşasına sahip bireylerin pornografik materyalleri daha az tükettikleri yapılan çalışmalarda görülürken (Herrman ve Bornder, 1983; Lottes, Weinberg ve Weller, 1993; Perry, 2017; Ritts ve Engrebretson, 1991; Sherkat ve Ellison, 1997) pornografik materyalin kullanım hakları üzerine yürütülen bir diğer çalı̧̧mada eğitim seviyesi yüksek ve liberal değerlere sahip kesimlerin pornografik materyali daha sık tükettikleri ve bu davranışı doğal bir "hak" olduğu fikrinden yola çıarak değerlendirdikleri dikkat çekmektedir (Wu ve McCaghy, 1993). Bu araştırmalar bizlere pornografik materyalin tüketimini belirleyen birçok değişkenin olduğunu göstermektedir.

Pornografinin tüketim sıklığına ilişkin yapılan çalışmaları, pornografik materyalin bu tüketiminin sebepleri ve sonuçları üzerinde odaklanan çalışmalar izlemiştir. Özellikle tüketim amaçlarının kadınlar ve erkekler arasında farklılaştığına işaret eden çalışmalar bulunmaktadır. Wallmyr ve Welin (2006), tüketim sıklı̆̆ının yanında tüketim amacını da inceledikleri 
çalışmalarında erkeklerin büyük oranının cinsel uyarılma yaşamak ve kendini tatmin etmek sebebiyle, kadınların ise merak nedeniyle pornografik materyali tükettikleri sonucuna ulaşmışlardır. Wallymr ve Welin bu durumu, ilişkilerinde erkeklerin daha çok cinsel, kadınların ise daha çok duygusal beklentiler içerisinde olduğu argümanına bağlamaktadırlar. Rogala ve Tydén (2003) de pornografik materyalin tüketiminin hem sebep hem de sonuçlarını inceledikleri araştırmalarında, kadınların pornografik materyali tüketme sebeplerinin, cinselliği öğrendikleri bir alan olarak değerlendirmeleri olduğunu gözlemlemişlerdir. Ayrıca pornografik materyalleri tüketen kadınlarda, cinselliği öğrenme amacı ile ilişkili bir biçimde bazı cinsel birleşme türlerinin (anal, oral vb.) pornografik materyali tüketmeyen kadınlara göre daha çok gözlendiğini ifade etmektedirler. Bu sonuca yönelik getirilen ilk açıklama, bu cinsel birleşme türlerini talep eden erkeklerin eşlerinin, bu birleşme türlerini pornografik filmlerde görerek daha normal karş1lyyor olabilmeleriyken bir diğer açılama ise bu cinsel birleşme türlerini görüp öğrenen kadınların bu cinsel davranışları talep ediyor olmaları ihtimalidir. Her iki açıklama da kadınların pornografik materyal tüketimleriyle beraber cinsellik yaşantılarına ilişkin yeni davranışsal tecrübeler edindiklerini göstermektedir.

Pornografik materyalin tüketiminin bir diğer sonucu olarak ele alınan cinsel tatmin düzeylerinin incelendiği bir araştırmada porno izleme davranışının erkeklerde düşük cinsel tatmin oranıyla kadınlarda ise yüksek tatmin oranıla ilişkili olduğu görülmüss ve kadınlardaki bu ilişkinin pornografinin cinsellik üzerindeki öğretici etkisi sebebiyle olabileceğine vurgu yapılmıştır (Poulsen, Busby ve Galovan, 2013). Benzer bir bulgu da Bridges ve Morokoff'un (2011) çalışmasında görülmüş, erkeklerin porno izleme davranışının cinsel beraberlik sayısında azalmaya neden olurken kadınların porno izleme davranışının ise erkeklerdekinin tersine cinsel beraberlik sayısında artışa sebep olduğu sonucuna ulaşılmıştır. Araştırmacılar bu durumu pornografinin öğretici yönünün yanında kadınların porno filmleri partnerleriyle izlemek isterken erkeklerin yalnız başlarına izleme talepleriyle de ilişkilendirmektedirler. Pornografik materyallerin tüketimlerine ilişkin bu sonuçlar bizlere kadın ve erkekler arasında pornografik materyalle ilişkilenme biçimlerinde farklılıklar olduğunu göstermektedir. Ve pornografik materyaller ile farklı ilişkilenme biçimleri, farklı tutumların ortaya çıkmasına da sebep olabilmektedir.

Pornografik materyal ile ilişkilenme biçimlerinde cinsiyetler arası farkları pornografinin işlevsel ve içerikle ilişkili yönlerine ilişkin algılarla açıklayan çalışmalar bulunmaktadır. Schneider (2000), partnerlerinin porno izlemelerinin kadınların reddedilmiş ve önemsiz hissetmelerine yol açtığını belirtmektedir. Bu durum kadınların pornografik materyalin içeriğine değil, kendi hayatları ve ilişkileri üzerindeki işlevine de odaklandıklarına dikkat çekmektedir. O’Reilly, Knox ve Zusman (2007) yaptıkları çalışmalarında erkeklerin ilişkide bulundukları partnerlerinin pornografik materyaldeki kişiyi hayal etme davranışını sorun etmediklerini görmüşlerdir. Kadınların ise bu durumdan rahatsız oldukları sonucuna ulaşılmıştır. Bu durumdan rahatsız olduğunu belirten kadınlar, kendilerini bir rekabet ortamı içerisinde bulduklarını, ihanete uğramış olduklarını, eşleri için yeterince iyi olmadıklarını düşündüklerini, reddedilmiş hissettiklerini belirtmişlerdir. Pornografik materyalin tüketimini sadece işlevsel yönü olan içerdiği cinsellikle ilişkilendirirken kadınların, pornografi karşıtı feminist kuramların iddia ettiği gibi sadece içerikte bulunan ve hemcinslerine yönelik cinsiyetçi şiddet üzerinden değil aynı zamanda işlevi üzerinden kurguladıklarını göstermektedir.

Porno sektöründeki oyuncuların cinsiyetlerine yönelik üniversite öğrencilerinin algılarını incelendiği çalışmalarda, kadın oyuncuların erkek oyunculara nazaran bu alanda çalışmaktan daha az zevk aldıkları ve bu alana zorla itildiklerine yönelik bir algı olduğu görülmektedir (Griffith, Hayworth, Adams, Mitchell ve Hart, 2013; Polk ve Cowan, 1996). Evans-DeCicco ve Cowan (2001) erkeklerin bu sektöre "iş memnuniyeti" sebebiyle girdiklerine yönelik bir alg1 
olduğunu belirtmektedirler. Bu bulgular pornografi sektörünün erkekler için ilgi çekici bir alan olduğuna, ancak kadınları suistimal ettiğine yönelik bir algının bulunduğu anlamına gelmektedir. İlgili araştırma sonuçlarına göre erkekler, kadın ve erkek porno oyuncularına yönelik benzer tutumlar gösterirken; kadınlar, kadın porno oyuncularına yönelik daha olumsuz bir tutum sergilemektedirler. Bu fark, kadınların hemcins porno oyuncularından beklenen daha uçlardaki cinsel davranışların kendilerinden de beklenebileceğine ilişkin endişeleri ile açılanmıştır. Bu durum pornografik materyallerdeki cinsel davranışların erkekler için hoş görülebilir sınırlar içerisindeyken bu davranışların beklenebileceği kadınlar açısından rahatsız edici sınırlar içerisinde olduğunu düşündürmektedir. Pornografi kadınların normal hayatlarında var etmemeleri gerektiği düşünülen cinsel bir içeriğe sahiptir, pornografideki cinsel davranışlar günlük hayatta değil ancak pornografik materyallerde normal karşılanmaktadır.

Johansson ve Hammarén (2007) yaptıkları çalışmada erkeklerin \%77,4'ünün kadınların ise \%28,4'ünün pornografiye yönelik olumlu tutum gösterdiklerini tespit etmişlerdir. Çalışmalarındaki analizler sonucunda üç gruplama yapılmıştır. Erkek sayısının fazla olduğu "porno düşkünleri" grubundaki katılımcilar, pornografiye yönelik daha olumlu bir tutum içerisinde olmalarının yanında pornografinin aşağılayıcı olmadığını belirtmektedirler. "Kararsızlar" şeklinde isimlendirilmiş bir diğer gruptaki bireyler, pornografiye yönelik olumlu bir tutum sergilerken pornografinin aşağılayıcı bir yönünün de bulunduğunu düşünmektedirler. Bu gruptaki erkek sayısı "porno düşkünleri" grubundaki kadar olmasa da kadınlardan fazladır. Kadınların çoğunlukta olduğu "Porno karşıtları" denilen üçüncü gruptaki bireyler ise pornografinin aşağılayıcı olduğunu belirtmekte ve pornografideki içeriğin bir şekilde sınırlandırılmasını istemektedirler. Çalışmanın önemli bir başka bulgusu da pornografinin sadece erkekler için değil kadınlar için de var olan bir materyal olduğu algısıdır. Araştırmacılar, kadınların pornografiye yönelik olumsuz tutumlara sahip olmasına rağmen pornografik materyalin kadınlar için de olduğu düşüncesini işlevsel ve içerik temelli bir ayrıştırma ile açılamaktadırlar. Bu çalışmanın önemli bir göstergesi pornografik materyalin, işlevi yani genel kullanım amacı ile değil içeriğinin sunuluş biçimi ile kadınları aşağılıyor şeklinde algılanıyor olduğudur. Yani pornografi karşıtı feministlerden McCormack'in vurguladığı gibi (1993) pornografik hikayelerde kullanılan kadın ve erkek kimliklerinin ne şekilde sunulduğu önem kazanmaktadır. Kadınlar, pornografik materyali tüketmekten erkekler gibi keyif almakta, ancak bu materyallerin inşa ettiği "erkek" ve "kadın" kimlik ve rollerini rahatsız edici ve aşağılayıcı bulmaktadırlar.

Kadınlar için hem haz verici hem de aşağılayıcı bir anlamı olan pornografide ortaya çıkan bu ikilemi Parvez (2006), kadınların geçmiş yaşamlarındaki şiddet ile ilişkilendirmekte ve bu sayede kadınların haz aldıklarını ifade ettikleri pornografik materyale karşı çelişkili duygular yaşadıklarını belirtmektedir. Parvez bu araştırmasında, kadınların kişisel uyarılma noktasında pornografik materyalden haz almalarının yanında bundan rahatsızlık da duymalarının iki sebebi olduğunu ortaya koymaktadır. Birinci sebep kadınların bireysel olarak geçmiş yaşantılarında deneyimlemiş oldukları şiddet içeren cinsel tecrübeleridir. İkinci sebep ise kadınların, porno filmlerdeki kadın oyuncuların gerçekmiş gibi gözüken şehvet ve hazlarına ilişkin duydukları şüphedir. Materyallerde hemcinslerinin yaşadığı şehvet ve hazzın gerçekliğine ilişkin şüpheler, istemedikleri bir davranış göstermeye mecbur bırakılan hemcinslerine yönelik bir mağduriyet duygusu ortaya çıkarmakta ve keyif aldıkları pornografiye yönelik olumsuz tutumlar beslemelerine de sebep olmaktadır.

Pornografik materyallerde kullanılan kadın ve erkeklere biçilen rol ve kimliklerin, toplumdaki cinsiyetlerden beklenen rol ve davranışları düzenlemekte ve bir hiyerarşi yaratmadaki önemine dikkat çeken Amoah (1997) bu durumun sadece cinsiyetler arası değil ırklar arası bir iktidar ilişkisini de inşa ettiğini belirtmiş ve siyahi kadınların pornografiden en olumsuz şekilde 
etkilenen grup olduğunu iddia etmiştir. Ortada beyaz erkeğin en tepede bulunduğu, onu siyahi erkeğin takip ettiği, bunun ardından beyaz kadının ve en son basamakta siyahi kadının bulunduğu bir hiyerarşi kurulumu olduğunu belirten Amoah, pornografinin siyahi erkeğe kendisine tarih boyunca yasaklanmış olan beyaz kadına ulaşımı da sağladığını bu yüzden kadını küçük düşüren pornografik materyalin siyahi erkekler tarafından daha yoğun bir şekilde kullanıldığını ifade etmektedir. Kadın her koşulda pornografi içerisinde ezilen konumda iken beyaz erkekler lehine ırksal bir hiyerarşi olsa dahi erkek her daim pornografinin güçlü öznesi olarak konumlandırılmaktadır.

\section{Çelişik Duygulu Cinsiyetçilik Kuramı ve Pornografi}

Pornografiye getirilen eleştirilerin büyük kısmı temelini erkek ve kadınlar arasındaki toplumsal cinsiyet rollerini erkeğin lehine düzenleyip kadını nesneleştiren cinsiyetçi bir materyal olduğu fikrinden almaktadır (Amoah, 1997; Bart, 1980; Diamond, 1985; MacKinnon ve Dworkin, 1997). Yapılan çalışmalar göstermiştir ki pornografik materyal tüketimi ile düşmanca cinsiyetçiliğin artışı arasında pozitif yönlü bir ilişki bulunmaktadır (Hald, Malamuth ve Lange, 2013; Harris, Thai ve Barlow, 2016; Shim ve Paul, 2014). Bem (1983) toplumsal cinsiyete ilişkin şemaların çocukların kendi bilişsel süreçlerinin sonucu oluştuğunu belirtir ancak bu şemaların yine toplumun, cinsiyete göre farklılaşan pratiklerine göre şekillenmiş olduğunun da altını çizer. Yetişkinlerin çocuklarda, küçük bir kızın güçlü olabilmesi gibi, yıllarca pekişmiş cinsiyet şemalarına uymayan özellikleri fark etmediklerini, dolayısıyla da bu duruma ilişkin herhangi bir yorumda veya işaretlemede bulunmadıklarını belirtir. Toplumun şemalarıyla uyuşmayan bu tür özelliklere dikkat çekilmemesi ve bunların pekiştirilmemesi, çocukların yetişkinler gibi benzer şematik seçiciliği kendileri için uygulamalarına, kendi kişiliklerinin olası birçok boyutu içerisinden, sadece toplum ile uyumlu olanı seçmelerine yol açmaktadır. Toplumun yapısına uyumlu olacak şekilde ortaya çıkan, cinsiyet rollerinin farklarına dayalı bu bilişsel seçilim, bireylerin benlik şemalarını cinsiyete dayalı bir çerçevede inşa etmesine sebep olmaktadır (Bem, 1983). Butler (1997) de toplumsal cinsiyet rollerinin, biyolojik cinsiyet farklılıklarını temel alarak kendilerine cinsiyetçi bir yol çizdiğini belirtmektedir. Cinsiyetçilik kavramını çalışan Glick ve Fiske (1996) de ortaya attıkları "çelişik duygulu cinsiyetçilik" kuramı ile erkeklerin kadınlara yönelik cinsiyetçi tutumlarının sadece olumsuz ve düşmanca davranışları değil, korumacı davranışları da içerdiğini belirtmektedirler. Cinsiyetçilik sadece düşmanca bir tutumu içermek zorunda değildir, karşı cinsin korunmaya muhtaç olduğu fikri de cinsiyet ayrımcılığının bir parçasıdır. Toplum içerisinde birlikte yaşayan tüm cinsel kimliklerin de birbirlerine karşı önyargıları bulunduğunu hatırlatan Glick ve Fiske (1999), kadınların da erkeklere yönelik iki uçlu cinsiyetçi tutumlar içerisinde bulunduğuna işaret ederler. Araştırmacılar kadınların erkeklere yönelik cinsiyetçi tutumlarını da düşmanca ve korumacı olarak iki alt faktörde incelemişlerdir. $\mathrm{Bu}$ çalışmada feminist teorilerin iddia ettiği üzere pornografinin kadına yönelik şiddet içermesi Glick ve Fiske'nin kuramlarında bulunan "düşmanlık" alt faktörü ile ilişkilendirilebilmektedir. Düşmanlık alt faktörünün ilk boyutu olan ataerkilliğe içerleme, erkeklerin sosyal hayat içerisindeki baskın statüsünü ve kadınlar üzerinde olan otoritesini hedef almaktadır. Cinsiyetler arası ödünleyici farklılaştırma boyutunda, kadınlar sahip olduklarını algıladıkları olumlu özellikleriyle kendilerini olumsuz özelliklere sahip erkeklerden ayırmaktadırlar. Heteroseksüel düşmanlık ise erkeklerin kadınlara karşı cinsel saldırganlık göstermeleri sonucu oluşmaktadır. Her üç boyutun da pornografinin içerdiği iddia edilen nesneleştirilen, cinsiyetçi şiddete maruz kalan kadın algısıyla ilişkilendirilebileceği bu yüzden de kadınların erkeklere yönelik düşmanca tutumları ile pornografiye yönelik tutumları arasında bir korelasyon gözlenebileceği düşünülmektedir. 


\section{Araştırmanın Amacı}

Türkiye'de pornografiye yönelik alg1 ve tutumlar ile ilişkili bir görgül çalışma bulunmamaktadır. Özellikle içerdiği iddia edilen cinsiyetçi şiddet düşünüldüğünde, cinsiyetler arası şiddet ve ayrımcilı̆̆n sıkça konuşulmakta olduğu Türkiye'de, cinsiyetçiliğin ve cinselliğin farklı algılamalarına etki edebilen "pornografi" kavramına yönelik tutumların araştırıldığı bir çalışmanın önemi ortadadır. Sosyolog Lena Berg (1999, akt. Johansson ve Hammarén, 2007) kadınların pornografiyi sevmemeyi toplumsal olarak "öğrendiklerini" belirtmektedir. Pornografinin içerdiği düşünülen cinsiyetçi şiddetin yanında farklı algıların da bu toplumsal öğrenilmişlik üzerinde etkisi bulunmaktadır. İçerdiği cinsiyetçi şiddetin erkeklere ilişkin düşmanca tutumlar ile ne kadar ilişkilendirilerek pornografiye yönelik tutumları belirleyeceğini incelemek yapılmış olan bu çalışmanın temel amacıdır. Pornografideki kadın ve erkeklerin nesneözne konumlandırmaları göz önünde bulundurularak toplumsal cinsiyet rollerine yönelik tutumların etkisi de araştırmada incelenmiştir.

Pornografiye yönelik tutumlarla ilgili bu araştırmada, çelişik duygulu cinsiyetçilik ve toplumsal cinsiyet rollerine ilişkin tutumlar çerçevesinde aşağıdaki hipotezler geliştirilmiştir;

H1: Pornografik kadınları nesneleştiren bir materyal olduğu ve cinsiyetçi şiddet içerdiği fikrinden yola çıkarak kadınların erkeklere nazaran pornografiye yönelik daha olumsuz bir tutum sergileyecekleri beklenmektedir.

H2: Cinsiyet eşitliğini önemseyen bireylerin pornografinin içerdiği iddia edilen cinsiyet ayrımcılığından rahatsız olacağı beklentisiyle toplumsal cinsiyet rollerine ilişkin tutumlar (TCR) ile pornografiye yönelik tutumlar (PYT) arasında negatif yönlü bir ilişki bulunacağı düşünülmektedir.

H3: Pornografik materyalde erkeklerin özne kadınların ise nesne konumunda bulunduğu fikrinden yola çıkarak toplumsal cinsiyet rollerine ilişkin tutumlar ile pornografiye yönelik tutumlar arasındaki ilişkide cinsiyetin biçimlendirici etkisi olacağı beklenmektedir.

H4: Erkeklerin öznesi olduğu düşünülen pornografik materyalde içerildiği iddia edilen cinsiyetçi şiddetin erkeklere yönelik düşmanca bir tutum ortaya çıkaracağ 1 düşünülmektedir. Bu yüzden kadınlarda, toplumsal cinsiyet rollerine ilişkin tutumlar ile pornografiye yönelik tutumları arasındaki ilişkide, erkeklere ilişkin düşmanca tutumlarının (EDT) biçimlendirici etkisi olacağı, bu etkinin ise erkeklerde gözlenmeyeceği beklenilmektedir.

H5: Erkeğin bir özne ve ayrımcı şiddetin faili şeklinde inşa edildiği pornografide ortaya çıkacak erkeğe ilişkin düşmanca tutumların, kadınlarda bu şiddetin mağduru olmaları sebebiyle erkeklere nazaran daha çok gözleneceği düşünülmektedir. Bu yüzden erkeklere ilişkin düşmanca tutumlar ile pornografiye yönelik tutumlar arasındaki ilişkide cinsiyetin biçimlendirici etkisi olacağ 1 beklenmektedir.

\section{YÖNTEM}

\section{Katılımcilar}

Çalışmaya, internet üzerinden ulaşılan ve bilgilendirilmiş onam formunu doldurup onay vermeyi kabul eden 400'ü kadın (\%59.6), 271'i erkek (\%40.4) olmak üzere toplam 671 kişi katılmıştır. Katılımcıların yaşları 18 ile 65 arasındadır ve ortalaması 27.65 'tür $(S=7.31)$. Katılımcıların 549'u (\%81.8) bekârdır ve 633'ü (\%94.5) üniversite öğrencisi veya mezunudur. Katılımcıların 303'ü (\%45.2) düzenli bir cinsel hayatları olduğunu bildirmişlerdir. 


\section{Veri Toplama Araçları}

Araştırmada demografik bilgilerin toplandı̆̆ı Kişisel Bilgi Formu, Pornografiye Yönelik Tutum Ölçeği, Erkeklere İlişkin Çelişik Duygular Ölçeği ve Toplumsal Cinsiyet Rolleri Tutum Ölçeği kullanılmıştır.

Kişisel Bilgi Formu Katılımcıların yaş, cinsiyet, eğitim durumu, medeni durumu, duygusal ilişki süreleri ve düzenli cinsel ilişki sürelerine ilişkin bilgiler toplanmıştır.

Pornografiye Yönelik Tutum Ölçeği (PYT) Wood'un (2013) geliştirmiş olduğu, insanların pornografiye yönelik tutumlarını ölçen 15 maddelik bir ölçektir. Maddeler 1 "Kesinlikle katılmıyorum" ile 7 "Kesinlikle katılıyorum" arasında değerler alan likert tipi derecelendirme ile değerlendirilmiştir. Orijinal ölçek için oluşturulmuş 66 madde yaşları 18 ile 46 arasında değişen 90'1 erkek 90'ı kadın olan toplam 180 katılımcıya uygulanmıştır. Faktör analizi yapıldıktan sonra varyansın \%25.43'ünü açıklayan ilk faktörün içerisindeki 15 madde pornografiye yönelik tutumlar ölçeği için kullanılmıştır. Maddelerin faktör yükleri 0.41 ile 0.80 arasındadır ve Cronbach alfa sayısı .89 olarak bulunmuştur.

Ölçek Çoker (2015) tarafından Türkçe'ye çevrilmiş, sosyal psikoloji alanında doktorasını yapmış bir araştırmacı tarafından çevirinin ve dil eşdeğerliliğinin kontrol edilmesinin ardından uygulanmıştır. Bu ölçek Türkiye'de pornografiye yönelik kullanılmış ilk tutum ölçeğidir. KMO katsayısı .927 olarak bulunmuştur. Bartlett testinin sonucu da $\left(x^{2}=4489.15, p<.001\right)$ yüksek düzeyde anlamlıdır. Faktör analizi sonuçlarına göre ölçek toplam varyansın \%53,64'ünü açılayan iki alt faktörden oluşmaktadır. Bir alt faktör, faktör yükleri .63 ile .77 arasında değişen maddelerden oluşan olumlu tutumlar faktörü, ikincisi madde faktör yükleri .41 ile .75 arasında olan olumsuz tutum alt faktörüdür. Çalışmada 1, 4, 5, 6, 10, 11, 14 ve 15'inci sorular tersine puanlanarak kullanılmaktadır. Maddelerden alınan toplam puan katılımcıların pornografiye yönelik tutumlarını belirtmektedir. Katılımcının ölçekten aldığı yüksek puanlar pornografiye yönelik daha olumlu tutuma sahip olduğunu göstermektedir.

Erkeklere İlişkin Çelişik Duygular Ölçeği'nin Düşmanca Tutumlar Alt Boyutu (EDT) Glick ve Fiske (1999) tarafından erkeklere yönelik cinsiyetçi tutumları ölçmek amacıyla geliştirilen Erkeklere İlişkin Çelişik Duygular Ölçeği 19 maddeden oluşmaktadır. Erkeklere ilişkin düşmanca tutumlar (EDT) alt boyutunda 10, erkeklere ilişkin korumacı tutumlar (EKT) alt boyutunda 9 madde bulunmaktadır. Her bir alt boyutun maddeleri 1 "tamamen karşıyı" ile 6 "tamamen katılıyorum" arasında değer alan Likert tipi bir ölçek üzerinden değerlendirilmektedir. Orijinal ölçeğin Cronbach Alfa katsayıları .83 ile .87 arasında, EDT alt boyutu için .81 ile .86 arasında ve EKT alt boyutu için .79 ile .83 arasında bulunmuştur.

Ölçek Sakallı-Uğurlu (2008) tarafından Türkçe'ye uyarlanmıştır. Uyarlama çalışmasında ölçeğin Cronbach Alfa katsayısı .82, EDT için .82 ve EKT için .83 olarak bulunmuştur. Bu çalışmada ölçeğin Erkeklere İlişkin Düşmanca Tutumlar boyutu kullanılmıştır. Bu boyuttan elde edilen yüksek puan erkeklere ilişkin düşmanca tutumlara sahip olunduğunu göstermektedir. EDT alt boyutunun bu çalışma için elde edilen Cronbach Alfa katsayısı .86 olarak hesaplanmıştır.

Pornografinin içeriğinde olduğu iddia edilen cinsel şiddet ve cinsiyetçiliğin, erkeklere yönelik düşmanca bir tutum ortaya çıaracağı düşünüldügünden bu çalışmada erkeklere ilişkin düşmanca tutumlar alt ölçeği kullanılmıştır.

Toplumsal Cinsiyet Rolleri Tutum Ölçeği (TCR) Zeyneloğlu ve Terzioğlu (2011) tarafından insanların toplumsal cinsiyet rollerine yönelik tutumlarını ölçmek için geliştirilen ve 38 maddeden oluşan ölçeğin bu çalışmada bulunan Cronbach Alfa değeri .92'dir. Maddeler 1 "Tamamen karşıyım", 5 "Tamamen katılıyorum" arasında değer alan Likert tipindeki bir ölçekle puanlanmaktadır. "Eşitlikçi Cinsiyet Rolü" (8 Madde), "Kadın Cinsiyet Rolü" (8 Madde), 
"Evlilikte Cinsiyet Rolü" (8 Madde), "Geleneksel Cinsiyet Rolü" (8 Madde) ve "Erkek Cinsiyet Rolü" (6 Madde) olarak adlandırılan 5 alt boyuttan oluşmaktadır. "Eşitlikçi Cinsiyet Rolü" kadın ve erkeklerin günlük yaşam içerisindeki sorumlulukları eşit biçimde paylaşılmalarına ilişkin maddeleri içerirken, "Kadın Cinsiyet Rolü" kadına toplum tarafından yüklenen sorumluluklara, "Evlilikte Cinsiyet Rolü" toplumun kadın ve erkeğe, evlilik içi yüklediği sorumluluklara, "Geleneksel Cinsiyet Rolü" toplumun kadın ve erkeğe günlük yaşam içerisinde yüklediği sorumluluklara, "Erkek Cinsiyet Rolü" ise toplum tarafından erkeğe yüklenen sorumluluklara ilişkin maddeleri içermektedir. Ölçekten alınan yüksek puanlar katılımcının toplumsal cinsiyet rollerine ilişkin eşitlikçi bir tutuma sahip olduğuna işaret ederken düşük puanlar daha geleneksel bir tutuma sahip olduğuna işaret etmektedir. Bu çalışmada ölçeğin Cronbach Alfa katsayısı .92 olarak bulunmuştur.

Yapılan bu çalışmada alt faktörler ayrıca incelenmediği için bulgular kısmında adı geçen "eşitlikçi" ve "geleneksel" kavramları ölçekten alınan toplam puanlara işaret etmektedir.

\section{İşlem}

Çalışma, katılımcıların rahatlık ve güvenlik hissiyatları düşünülerek internet üzerinden yürütülmüştür. Anket formlarının kartopu yöntemiyle sosyal ağlarda dağıtımları sağlanmıştır. Ölçeklerin doldurulması yaklaşık 20 dakika sürmektedir. Bulgular SPSS 24 kullanılarak analiz edilmiştir.

\section{BULGULAR}

\section{Hipoteze İlişkin Bulgular}

Katılımcıların cinsiyetlerine göre Pornografiye Yönelik Tutumlar, Toplumsal Cinsiyet Rollerine Yönelik Tutumlar ve Erkeklere Yönelik Düşmanca Tutumlar puanlarının ortalama, standart sapma değerleri Tablo 1'de sunulmuştur.

Tablo 1. Katılımcıların Cinsiyetlerine Göre Pornografiye Yönelik Tutum, Toplumsal Cinsiyet Rollerine İlişkin Tutum ve Erkeklere İlişkin Düşmanca Tutum Puan Ortalamaları, Standart Sapma Değerleri

\begin{tabular}{|c|c|c|c|c|c|c|}
\hline \multirow{2}{*}{$\begin{array}{l}\text { Grup } \\
\text { Değişken }\end{array}$} & \multicolumn{3}{|c|}{ Kadın } & \multicolumn{3}{|c|}{ Erkek } \\
\hline & $\mathbf{N}$ & $\bar{x}$ & SS & $\mathbf{N}$ & $\bar{x}$ & SS \\
\hline $\begin{array}{l}\text { Pornografiye Yönelik } \\
\text { Tutumlar }\end{array}$ & 400 & 72.56 & 19.35 & 271 & 76.14 & 18.32 \\
\hline $\begin{array}{l}\text { Toplumsal Cinsiyet Rollerine } \\
\text { İlişkin Tutumlar }\end{array}$ & 400 & 174.2 & 11.05 & 271 & 164.89 & 18.04 \\
\hline $\begin{array}{l}\text { Erkeklere İlişkin Düşmanca } \\
\text { Tutum }\end{array}$ & 400 & 37.41 & 11.11 & 271 & 32.2 & 10.6 \\
\hline
\end{tabular}

İlk hipotezin analizinde erkek ve kadın katılımcıların PYT ölçeğinden aldıkları puanlar arasındaki fark bağımsız örneklemler t-testi ile incelenmiş ve elde edilen farkın anlamlı olduğu 
görülmüştür $(\mathrm{t}(669)=-2.4, \mathrm{p}<.05)$. Erkeklerin pornografiye yönelik tutumlarının (Ort. $=76.14, \mathrm{~S}=$ 18.32) kadınlara (Ort. $=72.56, S=19.35)$ göre daha olumlu olduğu anlaşılmıştır.

\section{Hipoteze İlişkin Bulgular}

İkinci hipotezin analizinde, TCR ile PYT arasındaki ilişki düzeyini test etmek amacıyla yapılan Pearson korelasyon analizi sonucunda pozitif yönde anlamlı bir ilişki olduğu bulunmuştur $(r=$ $.26, \mathrm{p}<.01)$. Katılımcıların toplumsal cinsiyet rollerine ilişkin tutumları gelenekselden eşitlikçiye doğru gittikçe pornografiye yönelik tutumları olumlu yönde değişmektedir (Tablo 2).

Tablo 2. Araştırmanın Değişkenleri Arasındaki Korelasyon Analizine İlişkin Sonuçlar

\begin{tabular}{lccc}
\hline & PYT & TCR & EDT \\
\hline $\begin{array}{l}\text { Pornografiye Yönelik } \\
\text { Tutumlar }\end{array}$ & - & $.26^{*}$ & $-.107^{*}$ \\
Toplumsal Cinsiyet Rollerine & & & \\
$\begin{array}{l}\text { İlişkin Tutumlar } \\
\text { Erkeklere İlişkin Düşmanca }\end{array}$ & $-.13^{*}$ \\
Tutum & & & \\
${ }^{*} p<.001$ & & & \\
\end{tabular}

\section{Hipoteze İlişkin Bulgular}

Üçüncü hipotezde, TCR ile PYT arasındaki ilişkide cinsiyetin biçimlendirici etkisini gözlemlemek amacıyla hiyerarşik doğrusal biçimlendirici regresyon analizi kullanılmıştır. TCR'nin yordayan değişken, cinsiyetin biçimlendirici değişken ve PYT'nin yordanan değişken olarak girildiği regresyon analizi sonuçlarına göre TCR puanları tek başına PYT ölçeğinden alınan puanların \%6.7'sini ( $\mathrm{p}<.001)$, cinsiyet puanları PYT ölçeğinden alınan puanların \%3.2'sini $(\mathrm{p}<.001)$ anlamlı düzeyde açıklamaktadır. Toplumsal cinsiyet rolleri ve cinsiyetin ortak etki puanının PYT ölçeğinden alınan puanlar üzerinde etkisi bulunmamaktadır (Tablo 3). Bu sonuçlara göre eşitlikçi toplumsal cinsiyet rollerine ilişkin tutumlar ile pornografiye yönelik tutumlar arasındaki ilişkide cinsiyetin biçimlendirici bir etkisi bulunmamaktadır.

Tablo 3. Cinsiyetin, Toplumsal Cinsiyet Rollerine ve Pornografiye Yönelik Tutumlar Arasındaki İlişki Üzerindeki Biçimlendirici Etkisine İlişkin Hiyerarşik Doğrusal Biçimlendirici Regresyon Analizi Sonuçları

\begin{tabular}{lllcccc}
\hline & Yordayıcı Değişkenler & $\mathrm{R}$ & $\mathrm{R}^{2}$ & $\mathrm{~F}$ & $\beta$ & $\mathrm{t}$ \\
\hline \multirow{2}{*}{ Aşama 1 } & $\begin{array}{l}\text { Toplumsal Cinsiyet } \\
\text { Rollerine İlişkin Tutum }\end{array}$ & .26 & .067 & 48.32 & $.26^{*}$ & 6.95 \\
\hline \multirow{2}{*}{ Aşama 2 } & $\begin{array}{l}\text { Toplumsal Cinsiyet } \\
\text { Rollerine İlişkin Tutum } \\
\text { Cinsiyet }\end{array}$ & .316 & .1 & 37.03 & $.32^{*}$ & 8.23 \\
& Toplumsal Cinsiyet & .32 & .102 & 25.36 & $.34^{*}$ & 8.01 \\
& $\begin{array}{l}\text { Rollerine İlişkin Tutum } \\
\text { Aşama 3 }\end{array}$ & & & & $-.2^{*}$ & -5.03 \\
& Cinsiyet & & & & -.06 & 1.39 \\
\hline${ }^{*} p<.001$ & Ortak Etki & & & & &
\end{tabular}




\section{Hipoteze İlişkin Bulgular}

Dördüncü hipotezde TCR ile PYT arasındaki ilişkide erkeklere ilişkin düşmanca tutumların biçimlendirici etkisinin kadınlarda gözlenirken erkeklerde gözlenmeyeceği beklenilmektedir. Kadınların TCR ve PYT ilişkisi üzerinde erkeklere ilişkin düşmanca tutumlarının biçimlendirici etkisinin incelendiği regresyon analizi sonuçlarına göre (Tablo 4); TCR puanları, PYT ölçeğinden alınan puanların \%7.9'ini anlamlı olarak açıklarken $(\mathrm{p}<$.001) EDT puanlarının PYT ölçeğinden alınan puanlar üzerinde bir etkisi bulunamamıştır. TCR ile EDT'nin ortak etki puanları ise PYT ölçeğinden alınan puanların \%1'ini açıklamaktadır $(\mathrm{p}<.05)$. Bu verilere göre kadınların toplumsal cinsiyet rollerine ilişkin eşitlikçi cinsiyet rolleri tutum düzeylerinin pornografiye yönelik tutumları üzerindeki etkisinde erkeklere ilişkin düşmanca tutumlarının biçimlendirici bir etkisinin olduğu söylenebilmektedir.

Tablo 4. Kadınlarda, Erkeklere Yönelik Düşmanca Tutumların, Toplumsal Cinsiyet Rollerine ve Pornografiye Yönelik Tutumlar Arasındaki İlişki Üzerindeki Biçimlendirici Etkisine Hiyerarşik Doğrusal Biçimlendirici Regresyon Analizi Sonuçları

\begin{tabular}{clccccc}
\hline & Yordayıı Değişkenler & $\mathrm{R}$ & $\mathrm{R}^{2}$ & $\mathrm{~F}$ & $\beta$ & $\mathrm{t}$ \\
\hline Aşama 1 & $\begin{array}{l}\text { Toplumsal Cinsiyet } \\
\text { Rollerine İlişkin Tutum }\end{array}$ & .28 & .079 & 34.28 & $.282^{* *}$ & 5.86 \\
\hline Aşama 2 & $\begin{array}{l}\text { Toplumsal Cinsiyet } \\
\text { Rollerine İlişkin Tutum } \\
\text { Erkeklere Yönelik } \\
\text { Düşmanca Tutumlar }\end{array}$ & .29 & .085 & 18.38 & $.259^{* *}$ & 5.15 \\
\hline $\begin{array}{l}\text { Toplumsal Cinsiyet } \\
\text { Rollerine İlişkin Tutum } \\
\text { Erkeklere Yönelik }\end{array}$ & .31 & .094 & 13.7 & $.307^{* *}$ & 5.54 \\
Aşama 3 & & & & -.077 & -1.53 \\
& $\begin{array}{l}\text { Düşmanca Tutumlar } \\
\text { Ortak Etki }\end{array}$ & & & & -.001 & -.02 \\
\hline
\end{tabular}

$" p<.05, " * p<.001$

Şekil 1'in incelendiğinde erkeklere yönelik düşmanca tutumları düşük olan kadınların toplumsal cinsiyet rollerine bakışları eşitlikçi tutuma yaklaştıkça pornografiye yönelik gösterdikleri olumlu tutumlarının, erkeklere yönelik düşmanca tutumları yüksek olan kadınlara göre belirgin derecede arttığı görülmektedir. Bu yüzden kadınlarda, toplumsal cinsiyet rollerine ilişkin eşitlikçi cinsiyet rolleri tutumlar ve pornografiye yönelik tutumlar arasındaki ilişkide erkeklere ilişkin düşmanca tutumların biçimlendirici etkisi bulunduğu söylenebilmektedir.

Dördüncü hipotezin ikinci basamağında erkeklerin TCR'nin PYT üzerindeki etkisinde EDT'nin biçimlendirici etkisi incelenmiştir (Tablo 5). Bulgulara göre; TCR puanlarının PYT ölçeğinden alınan puanların \%12'sini açıkladığı $(\mathrm{p}<.001)$, EDT puanlarının ise etkisinin olmadığ görülmüştür. TCR ve EDT'nin ortak etkileri ise PYT ölçeğinden alınan puanların \%3.4'ünü anlamlı düzeyde açıklamaktadır $(\mathrm{p}<.01)$. 


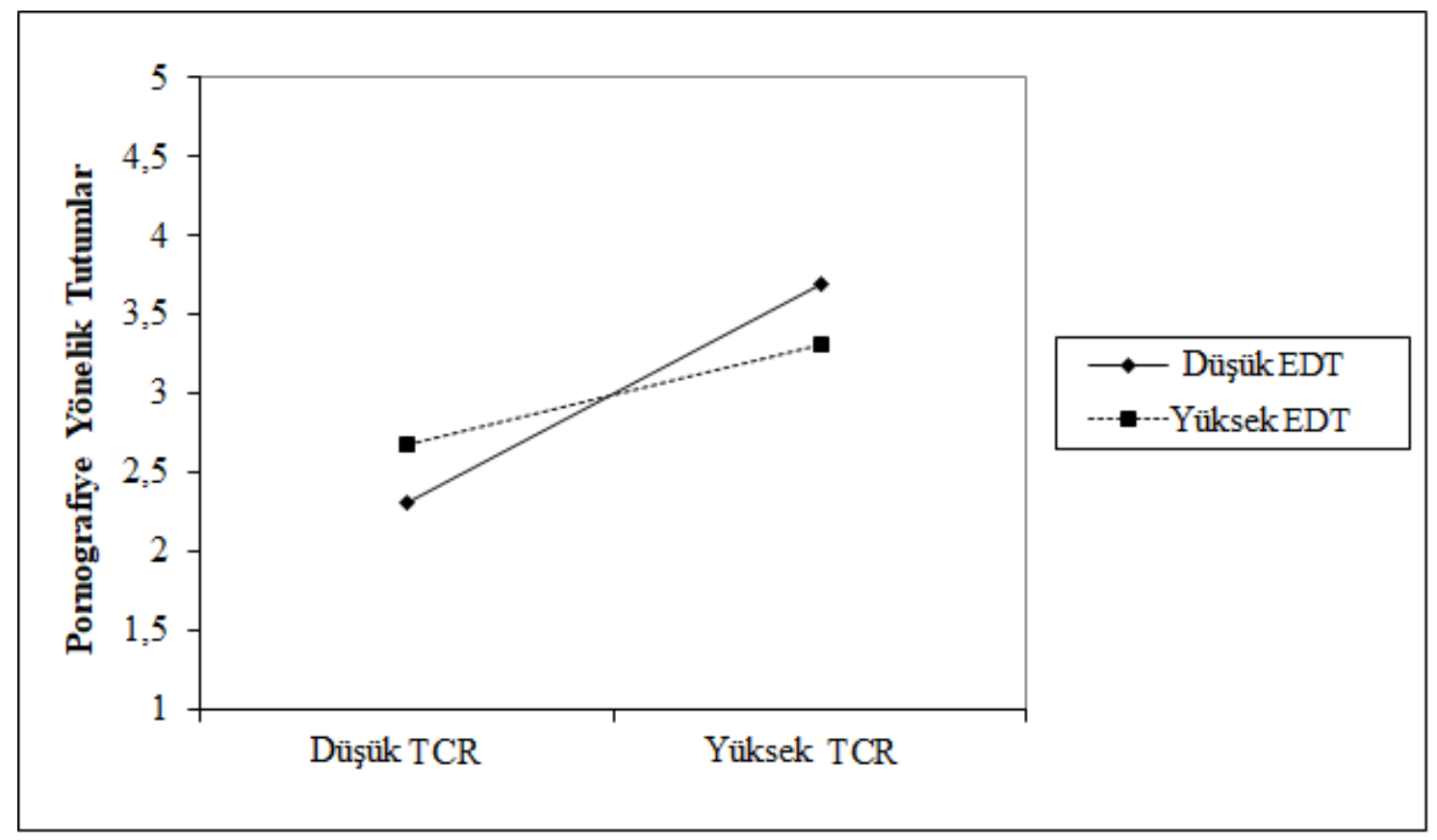

Şekil 1. Kadınlarda Erkeklere Yönelik Düşmanca Tutumların, Toplumsal Cinsiyet Rollerine ve Pornografiye Yönelik Tutumlar Arasındaki İlişki Üzerindeki Biçimlendirici Etkisi

Tablo 5. Erkeklerde Erkeklere Yönelik Düşmanca Tutumların, Toplumsal Cinsiyet Rollerine ve Pornografiye Yönelik Tutumlar Arasındaki İlişki Üzerindeki Biçimlendirici Etkisine İlişkin Hiyerarşik Doğrusal Biçimlendirici Regresyon Analizi Sonuçları

\begin{tabular}{clccccc}
\hline & Yordayıc Değişkenler & $\mathrm{R}$ & $\mathrm{R} 2$ & $\mathrm{~F}$ & $\beta$ & $\mathrm{t}$ \\
\hline \multirow{2}{*}{ Aşama 1 } & $\begin{array}{l}\text { Toplumsal Cinsiyet } \\
\text { Rollerine İlişkin Tutum }\end{array}$ & .346 & .12 & 36.65 & $.346^{* *}$ & 6.05 \\
\hline \multirow{2}{*}{ Aşama 2 } & $\begin{array}{l}\text { Toplumsal Cinsiyet } \\
\text { Rollerine İlişkin Tutum } \\
\text { Erkeklere Yönelik } \\
\text { Düşmanca Tutumlar }\end{array}$ & .353 & .125 & 19.14 & $.358^{* *}$ & 6.18 \\
\hline Aşama 3 & $\begin{array}{l}\text { Toplumsal Cinsiyet } \\
\text { Rollerine İlişkin Tutum } \\
\text { Erkeklere Yönelik } \\
\text { Düşmanca Tutumlar } \\
\text { Ortak Etki }\end{array}$ & .398 & .159 & 16.77 & $.332^{* *}$ & 5.79 \\
\hline
\end{tabular}

$" p<.01, "{ }^{*} p<.001$

Şekil 2'yi incelediğimizde erkeklere yönelik düşmanca tutumları düşük olan erkeklerin toplumsal cinsiyet rollerine bakışları eşitlikçi tutuma yaklaştıkça pornografiye yönelik gösterdikleri olumlu tutumlarının, erkeklere yönelik düşmanca tutumları yüksek olan hemcinslerine nazaran daha belirgin derecede arttığı söylenebilmektedir. Dolayısıyla erkeklerde toplumsal cinsiyet rollerine ilişkin eşitlikçi tutumlar eşitlikçi cinsiyet rolleri ve pornografiye yönelik tutumlar arasındaki ilişkide erkeklere ilişkin düşmanca tutumların biçimlendirici etkisi bulunduğu söylenebilmektedir. 


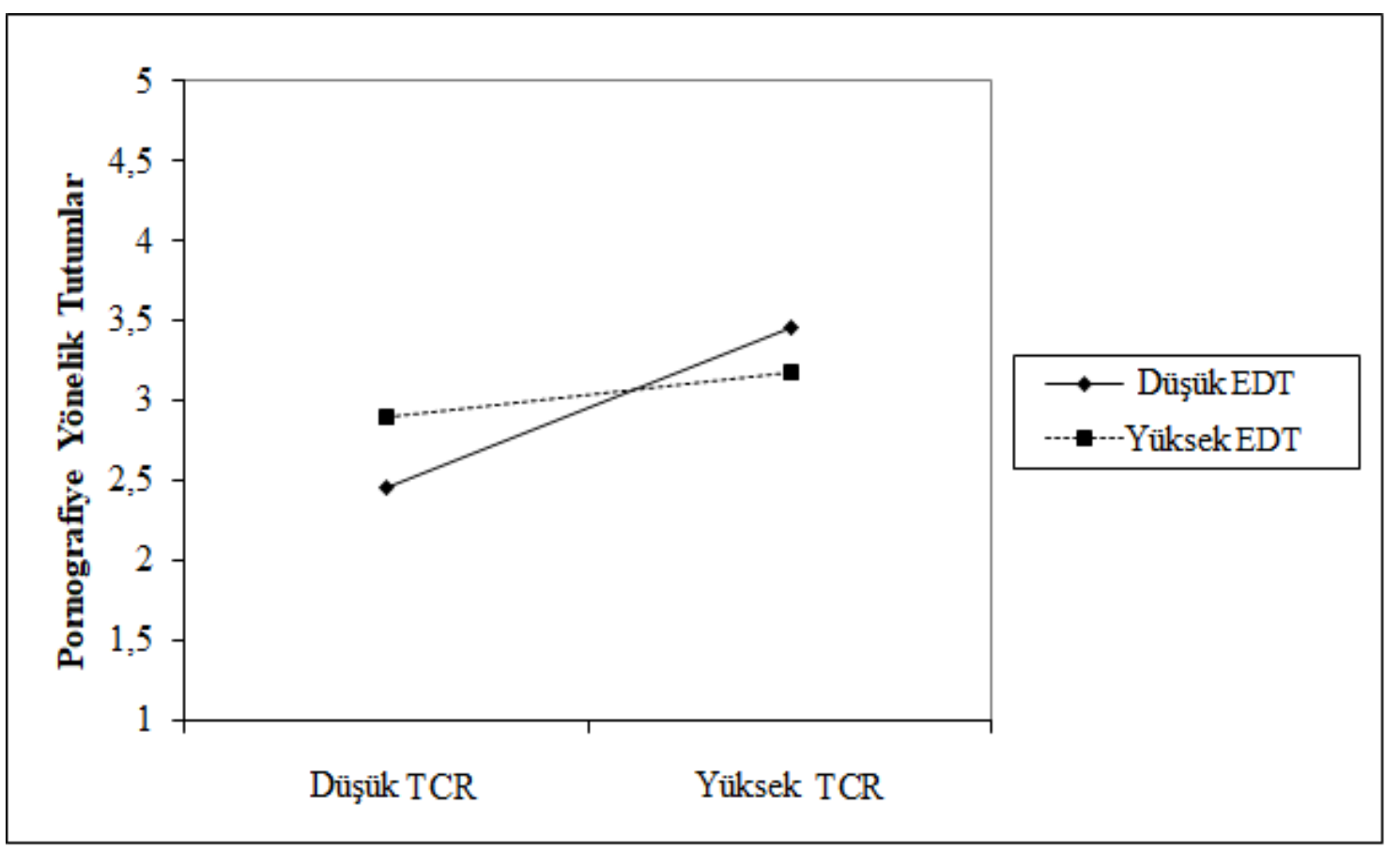

Şekil 2. Erkeklerde, Erkeklere Yönelik Düşmanca Tutumların, Toplumsal Cinsiyet Rollerine ve Pornografiye Yönelik Tutumlar Arasındaki İlişki Üzerindeki Biçimlendirici Etkisi

\section{Hipoteze İlişkin Bulgular}

Araştırmanın son hipotezinde EDT ile PYT arasındaki ilişkide cinsiyetin biçimlendirici etkisini görmek için EDT yordayan değişken, cinsiyet biçimlendirici değişken PYT da yordanan değişken olarak regresyona sokulmuştur (Tablo 7). Analiz sonuçlarına göre EDT puanlarının PYT ölçeği puanlarının \%1.2'sini anlamlı derecede açıklarken $(\mathrm{p}<.05)$ cinsiyet puanları PYT ölçeği puanlarının \%0.4'ünü anlamlı düzeyde açıklamaktadır $(\mathrm{p}<.05)$. EDT ve cinsiyet puanının ortak etkisi ise PYT ölçeği puanlarının \%0.7'sini anlamlı düzeyde açıklamaktadır ( $\mathrm{p}<.05)$.

Tablo 7. Cinsiyetin, Erkeklere Yönelik Düşmanca Tutumlar ve Pornografiye Yönelik Tutumlar Arasındaki İlişki Üzerindeki Biçimlendirici Etkisine İlişkin Hiyerarşik Doğrusal Biçimlendirici Regresyon Analizi Sonuçları

\begin{tabular}{llccccc}
\hline & $\begin{array}{l}\text { Yordayıcı } \\
\text { Değişkenler }\end{array}$ & $\mathrm{R}$ & $\mathrm{R} 2$ & $\mathrm{~F}$ & $\beta$ & $\mathrm{t}$ \\
\hline Aşama 1 & $\begin{array}{l}\text { Erkeklere Yönelik } \\
\text { Düşmanca Tutumlar }\end{array}$ & .107 & .012 & 7.82 & $-.107^{* *}$ & -2.8 \\
\hline \multirow{2}{*}{ Aşama 2 } & $\begin{array}{l}\text { Erkeklere Yönelik } \\
\text { Düşmanca Tutumlar }\end{array}$ & .128 & .016 & 5.57 & $-.091^{*}$ & -2.31 \\
& Cinsiyet & & & & -.072 & -1.82 \\
\hline \multirow{2}{*}{ Aşama 3 3} & $\begin{array}{l}\text { Eüşmanca Tutumlar } \\
\text { Cinsiyet }\end{array}$ & .152 & .023 & 5.27 & $-.086^{*}$ & -2.19 \\
& Ortak Etki & & & & $-.08^{*}$ & -2.03 \\
\hline${ }^{*} p<.05,{ }^{* *} p<.01$ & & & & $-.085^{*}$ & -2.15 \\
\hline
\end{tabular}


Şekil 3'ü incelediğimizde kadınların erkeklere ilişkin düşmanca tutumları arttıkça pornografiye yönelik gösterdikleri olumlu tutumlarının da erkeklerinkine göre belirgin derecede azaldığını görmekteyiz. Bu bulguya göre erkeklere ilişkin düşmanca tutumların pornografiye yönelik tutumlar üzerindeki etkisinde cinsiyetin biçimlendirici etkisinin bulunduğu söylenebilmektedir.

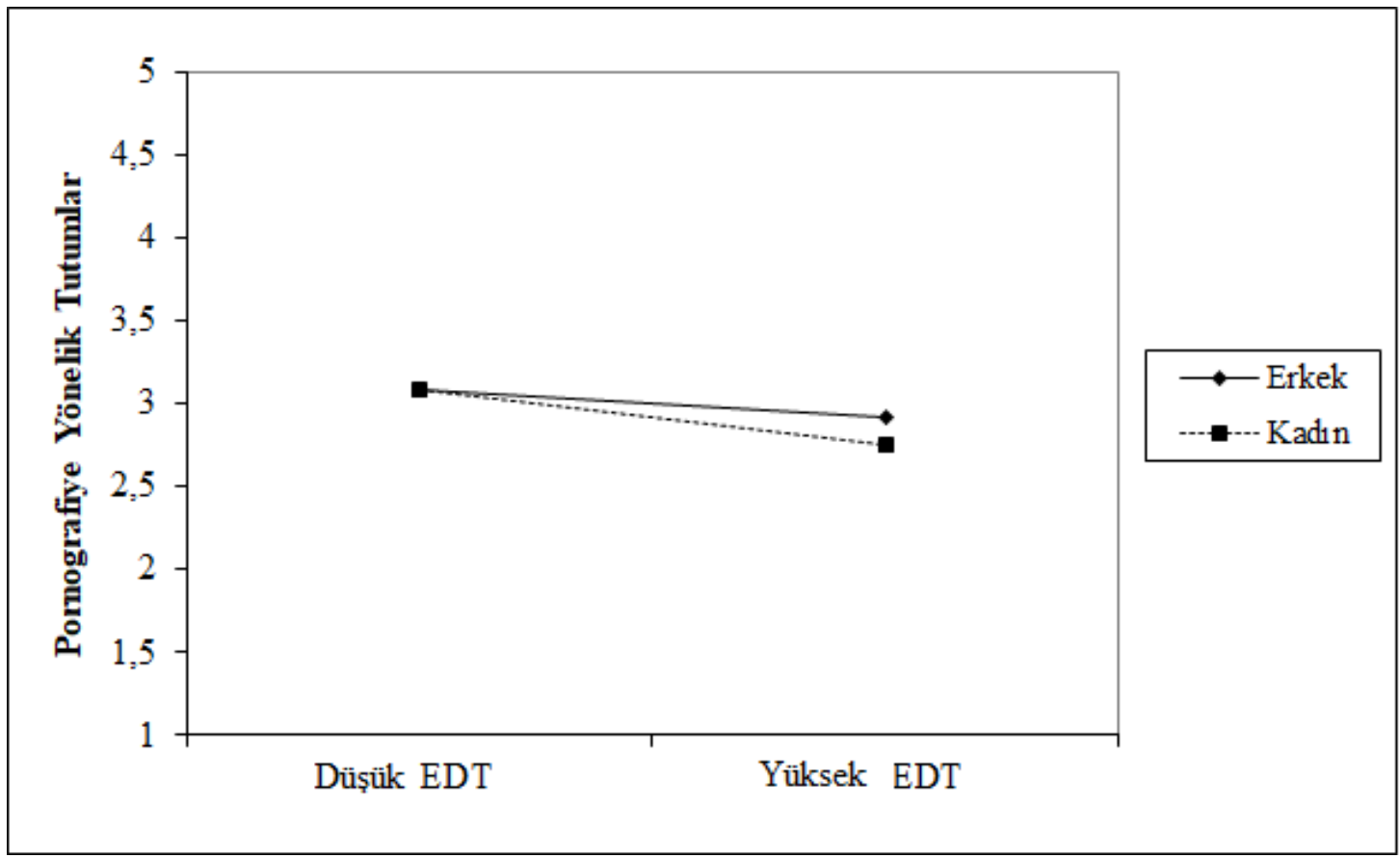

Şekil 3. Cinsiyetin, Erkeklere Yönelik Düşmanca Tutumlar ve Pornografiye Yönelik Tutumlar Arasındaki İlişki Üzerindeki Biçimlendirici Etkisi

\section{TARTIŞMA ve SONUÇ}

Bu çalışma pornografiye yönelik tutumları, feminist literatürün iddia ettiği üzere barındırmakta olduğu cinsiyetçi şiddet temelinde ele almaktadır. Pornografinin içerdiği cinsiyetçi şiddetin erkeklere ilişkin düşmanca tutumlar ile ne kadar ilişkilendirilerek pornografiye yönelik tutumları belirlediğini incelemek araştırmanın temel amacı iken pornografideki cinsiyete dayalı nesne-özne konumlandırmalarının etkilerinin de incelenmesi amaçlanmıştır.

İlk hipotezden beklendiği üzere, erkeklerin kadınlara nazaran pornografik materyallere yönelik daha olumlu bir tutum içerisinde bulundukları görülmektedir. Bunun nedenlerinden biri, kadınların pornografinin hem içeriksel hem de işlevsel boyutlarından erkeklerden daha fazla rahatsızlık duymaları olabilir (O'Reilly ve ark., 2007; Schneider, 2000). Pornografinin içeriksel boyutu göz önüne alındığında erkekler kadını nesneleştirdiği düşünülen bir materyalin öznesi konumundadırlar ve kadınların tersine, cinsiyetler arası ilişkiler ağının bu şekilde kurulmasından memnuniyet duyuyor olabilirler. İşlevsel açıdan da cinsiyetlerin pornografiyi algılamalarında farklılık bulunmaktadır. Kadınlar pornografik materyalin işlevsel boyutunu kişiselleştirmekte ve pornografik materyali, mücadele etmekte zorlandıkları bir rakip gibi görmektedirler (O'Reilly ve ark., 2007; Schneider, 2000). Wallmyr ve Welin'e (2006) göre erkekler pornografik materyali cinsel uyarım ve tatmin amacıyla tüketmektedirler dolayısıyla da cinsel bir arayış içerisindedirler. Kadınlar ise daha çok bir "merak" sonucu tüketim davranışına yönelmekte ve duygusal bir arayış içerisinde bulunmaktadırlar. Araştırmacılar pornografinin içerdiği cinselliğin erkeklerin bu arayışlarını giderdiğini ancak kadınların duygusal arayışıyla 
tezatlık oluşturduğunun altını çizmişlerdir. Bu sebeple hem işlevsel hem de içeriksel boyuttan memnun olan erkeklerin, her iki boyuttan da rahatsızlık duyan kadınlara göre pornografiye yönelik daha olumlu bir tutum sergiliyor olmalarının mümkün olduğu söylenebilir.

Çalışmanın ikinci hipotezindeki bulgular toplumsal cinsiyet rollerine ilişkin eşitlikçi tutuma sahip bireylerin pornografiye yönelik olumlu tutum gösterdiklerine işaret etmektedir. Bu durum son dönemde yapılan bazı çalışmalar ile de tutarlı gözükmektedir (Rasmussen ve Kohut, 2019; Kohut, Baer ve Watts; 2016). Bunun sebebi, pornografinin içerdiği belirtilen cinsiyetçi şiddetten çok işlevsel boyutundan dolayı pornografinin hem kadının hem de erkeğin eşit düzeyde tüketmeye hakkı olan bir materyal olarak algılanması olabilir. Diğer bir açıklama da geleneksel cinsiyet rollerine sahip bireylerin, pornografinin içerdiği cinsellikten, eşitlikçi cinsiyet rollerine sahip bireylere nazaran daha çok rahatsız olmalarıdır. Kahraman'ın (2010) bahsettiği "özel alan" içerisinde durması gereken cinselliğin genel alandaki ifşası, geleneksel tutumları benimseyen bireyler için çok önemli olan aile değerlerinin ve sınırlarının da bozulması anlamına gelmektedir. Bu yüzden kadını ve cinselliğini gözler önüne seren pornografinin toplumsal cinsiyet rollerine ilişkin geleneksel tutuma sahip bireyler tarafından daha olumsuz algılandığı düşünülebilir.

Araştırmanın üçüncü hipotezi, pornografik materyallerin içeriğinde kadınların nesne erkeklerinse özne olarak konumlandırıldığı fikrinden yola çıkarak toplumsal cinsiyet rollerine ilişkin tutumlar ile pornografi arasındaki ilişkide cinsiyetin biçimlendirici etkisi olacağ düşünülerek kurulmuştur. MacKinnon (1997) kadın üzerinde bir erke sahip olan erkeğin pornografi içerisindeki bu içerikten rahatsız olmayacağını, kadının ise bu içeriğin nesnesi olması sebebiyle rahatsızlık duyacağını belirtmiştir. Ancak araştırmanın bulgularına göre erkek ve kadınların toplumsal cinsiyet rollerine ilişkin tutumlarının pornografiye yönelik tutumlarını belirleme düzeyleri arasında anlamlı bir fark bulunamamıştır. Dolayısıyla pornografi içerisindeki cinsiyetçi şiddeti algılamada kadın ve erkekler arasında bir fark bulunmadığı iddia edilebilir. Burada şu soru karşımıza çıkmaktadır: İçerikteki cinsiyetçi şiddeti algılamada kadın ve erkek arasında bir fark yok mudur yoksa bu cinsiyetçi şiddet hiç mi algılanmamaktadır? Pornografinin içerdiği iddia edilen cinsiyetçi şiddetin algılanıp algılanmadığının ileride yapılacak çalışmalarla araştııılmasının alana önemli bilgiler katacağı düşünülmektedir.

Toplumsal cinsiyet rollerine ilişkin tutumlar ile pornografiye yönelik tutumlar arasındaki ilişkide erkeklere ilişkin düşmanca tutumların biçimlendirici etkisinin incelendiği dördüncü hipotez, pornografinin, öznesi erkek olan ve kadınları nesneleştiren bir materyal gibi algılanması sebebiyle kadınlarda bu biçimlendirici etkinin görüleceğini ancak erkeklerde böyle bir etkinin bulunmayacağını iddia etmektedir. Glick ve Fiske'nin (1999) kuramında erkeklerin sosyal hayattaki baskın statüsüne ve gücüne yönelik düşmanlığına karşılık gelen ataerkillik boyutu tam olarak bu hegemonik erkekliği hedefine oturtmaktadır. Elde edilen bulgulara göre sadece kadınlarda değil erkeklerde de bu biçimlendirici etki görülmektedir. Toplumsal cinsiyet rollerine yönelik tutumları eşitlikçiye yaklaşan kadın ve erkeklerin pornografik materyaldeki ataerkil güce dair algıları arttıkça pornografiye yönelik daha olumsuz tutumlar sergiledikleri söylenebilir. Hatta pornografiye yönelik tutumlar üzerindeki açıklayıcılık yüzdesine bakıldığında bu ortak etkinin erkeklerde kadınlarınkinden $\% 2$ daha yüksek bir açıklama gücüne sahip olduğu görülmektedir. Aradaki bu farkın sebebinin içerik boyutunun farkındalığı sebebiyle ortaya çıtığının düşünülmesi mümkündür. Kadının şiddete uğraması, nesneleştirilmesi, aşağılanması gibi niteliklerin pornografinin içeriksel boyutuna dair olduğu belirtilmektedir (Tibbets ve Blankenship, 1999). İşlevsel boyut ise erkeği eşitlikçi rollere darbe vuran bir şiddet öznesi olarak ele almaktansa pornografinin ilişkiler üzerindeki olumsuz etkileri üzerinde durmaktadır. Kadınların pornografinin içerdiği cinsiyetçi şiddeti algılamaları ancak pornografik materyalleri daha çok tüketmeleriyle mümkündür. Bridges ve Morokoff (2011) çalışmalarında kadınların daha çok cinsiyetçi şiddet ve hâkimiyeti barındırmayan pornografik materyalleri tükettiğini 
gözlemlemişlerdir. Dolayısıyla kadınların, erkeklerin öznesi konumunda bulundukları cinsiyetçi şiddet içeren pornografik materyallere erkekler kadar ulaşmamaları sebebiyle, erkeklere yönelik düşmanca tutumlara yol açabilecek cinsiyetçi şiddeti, erkekler kadar algılamıyor oldukları iddia edilebilir. Bu yüzden kadınlarda, toplumsal cinsiyet rollerine yönelik beklentilerinin pornografiye yönelik tutumlar üzerindeki etkisinde erkeklere yönelik düşmanca tutumlarının biçimlendirici bir etkisinin, erkeklerde olduğu kadar bulunmadığı söylenebilir. Bununla beraber eşitlikçi toplumsal cinsiyet tutumlarına sahip erkeklerin, pornografide algıladıkları cinsiyetçi şiddetten duydukları rahatsızlığı, özne konumlarına rağmen, pornografiye yönelik tutumlarına daha yoğun bir biçimde yansıttıkları düşünülebilir.

Araştırmanın beşinci hipotezine göre, erkeklere ilişkin düşmanca tutumların pornografiye yönelik düşmanca tutumları etkileme düzeyinde cinsiyetler arası bir fark olması beklenmektedir. Pornografide var olduğu belirtilen cinsiyetçi şiddet, ataerkil gücü hedef alan düşmanca bir tutuma yol açacaktır. Glick ve Fiske'e (1999) göre toplumda gözlenmekte olan erkeklere yönelik düşmanca tutumların sebebi erkeğin, kadını hedef alan, nesneleştiren bir güce sahip olup bunu kullanıyor olmasıdır. Bu yüzden kadınların bu gücün birincil nesneleri olmaları ve toplumsal hayat içerisinde bunun olumsuz sonuçlarını daha yoğun biçimde yaşıyor olmaları, erkeklere ilişkin düşmanca tutumları daha çok barındırıyor olmalarına sebep olacaktır. Erkeklerin ise hemcinslerine yönelik düşmanca tutumlarının, bu gücün sahibi olan tarafta bulunmaları sebebiyle pornografiye yönelik tutumlarını kadınlardaki kadar belirlemeyeceği düşünülmektedir. Araştırmanın bulguları da bu beklentiyi desteklemektedir. Kadınlar, pornografide kendilerine yönelik algıladıkları cinsiyetçi şiddet sebebiyle pornografiye yönelik olumsuz tutumlar beslemektedirler. Ancak bu durum, dördüncü hipotezde belirtilen "kadınların cinsel şiddet içeren pornografik materyali tüketmediği" açıklaması ile çelişmektedir. Pornografi karşıtı feministler, pornografinin içeriksel boyutunda kadına yüklenen anlam üzerinden cinsiyetçi şiddeti tartışmışlardır (Bart, 1985; Diamond, 1980; MacKinnon ve Dworkin, 1997). Dördüncü hipotezde, içeriksel boyutta karşılaşılan erkek şiddetinin kadının toplumsal varlığına bir tehlike oluşturması sebebiyle düşmanca bir tutuma yol açacağı dolayısıyla da toplumsal cinsiyet rollerine ilişkin tutumlar ile pornografiye yönelik tutumlar arasındaki ilişkide biçimlendirici bir etkisinin bulunacağı söylenmiş ve kadınların bu içeriğe erkekler kadar yoğun bir şekilde ulaşmamaları sebebiyle bu etkinin beklenildiği kadar şiddetli gözlenmiyor olabileceği belirtilmiştir. Ancak beşinci hipotez bu açıklamanın yeterli olmadığını göstermektedir. Pornografiye yönelik tutumlar ile erkeklere ilişkin düşmanca tutumlar arasındaki ilişki yalnızca içeriksel boyuttaki cinsiyetçi şiddet ile değil işlevsel boyutun ortaya koyduğu nedenselleştirmeler ile de belirleniyor gibi gözükmektedir. Pornografinin işlevsel boyutu cinsiyetçi şiddet ve ayrımı içermeyen ama erkeklerin pornografik materyali kullanmalarının yarattı̆̆ı sonuçları ve kadınların buna dair anlamlandırmaları üzerine odaklanmaktadır (O'Reilly vd., 2007; Schneider, 2000). Kadınlar pornografiyi erkeklerin kendilerini aldattıkları bir alan olarak da görüp kişiselleştirebilmektedirler. Bu durumun da pornografik materyali kullanan erkeklerin güvenilmez olduğu algısını ortaya çıkarmış olması mümkündür. Dolayısıyla da içeriksel boyutta kadının toplumsal rolünü hedef alan cinsiyetçi şiddetin değil işlevsel boyuta ilişkin algıların erkeklere ilişkin düşmanca tutumlar ve pornografiye yönelik olumsuz tutumlar arasındaki bağın bir sebebi olduğu söylenebilir.

Çalışma Türkiye'de yaşayan insanların pornografiye yönelik tutumlarını cinsiyetçilik bağlamında ölçmeyi amaçlamıştır. Çalışmanın önemli eksiklerinden biri cinsiyetin iki yönlü olarak ele alınması olmuştur. Biyolojik cinsiyetin belirleyiciliğinin yanı sıra toplumsal düzeyde belirleyicilik gücü yüksek "cinsel yönelim" kavramsallaştırması ve buna bağlı olarak Türkiye'de kendine yeni yeni yer bulmaya çalışan "queer" kuram çerçevesinde daha ayrıntılandırılmış bir 
şekilde ele alınacak bir "cinsiyet" değişkeni bizlere hem içeriksel hem işlevsel yönleriyle pornografinin anlaşılmasında çok daha önemli veriler sunacaktır.

Çalışmanın diğer bir kısıtlllığı da verilerin sadece 18 yaş üstündeki bireylerden toplanmış olmasıdır. Bilindiği gibi 18 yaş altı bireylerin bu tip çalışmalara katılımcı olarak katılabilmeleri için ebeveynlerinden izin alınması gerekmektedir. Oysa ki internetin bu kadar yaygınlaştı̆̆ 1 ve gençlerin pornografik materyallere ailelerinden habersiz şekilde ulaştıkları düşünüldüğünde, ailelerden izin alınmasının etik kurallar dahilinde olmasına rağmen gerçekçi bir duruş olmadığı düşünülmektedir. Ailelerinden gizli bu materyallere ulaşan gençlerin, ailelerinden izin aldıkları böyle bir çalışmaya ne derece dürüst cevaplar verecekleri önemli bir sorundur. Gençlerin pornografik materyallere ulaşabildiği ve bu süreci gizledikleri bir durumda politik doğrulardan yola çıarak, bu konuya ilişkin çalışmaları "etik ilkeler" ile sınırlamanın, onun bilinmez ve dokunulmamayı tercih edilen bölgede olmasına yol açmaktan ziyade bir işlevi bulunmayacaktır. Freud $(1930,2014)$ gençlere verilen eğitimi eleştirirken sadece cinselliği gizleyen bir biçime sahip olduğuna vurgu yapmaz. Eğitimdeki ahlakçılığın, gençlerden talep ettiği erdemliliği, başkalarının erdemli olduğuna inandırarak inşa etmeye çalıştı̆̆ını belirtir. Böylece eğitim, ahlaki korumacılığıyla gençleri hayatın gerçekliklerine hazırlamaktan geri kalmaktadır. Bilim de eğitim alanında yapılan bu korumacı yanlışa düşmekten imtina etmelidir. Çünkü var olduğu düşünülen bir soruna ilişkin çözümler, ancak o soruna yönelik doğru ve tarafsız bilgiye ulaşılabilmesinden geçmektedir. Pornografiye yönelik yapılacak ileriki çalışmaların bu etik sınırlılığa bir çözüm üretmesi önem arz etmektedir.

Çalışmanın hipotezleri feminist kuramları temel alarak oluşturulmuştur. Feminist kuramların pornografik materyallerde bulunduğunu belirttikleri cinsiyetçi şiddetin özellikle kadınların tutumlarını etkilemesinin yanında cinsiyet kimliklerine yönelik algıların, pornografiye yönelik tutumlar üzerinde tek belirleyici faktör olmadığı görülmektedir. Bunun yanında literatürdeki çalışmalarla tutarlı bir şekilde pornografik materyalin işlevinin de materyali tüketenler üzerinde etkilerinin olduğu düşünülmektedir. Ancak alanda yapılan çalışmaların azlığı hipotezlerin sonuçlarını kesin bir dille açıklamak noktasında yetersiz kalmaktadır. Ayrıca Türkiye'de konuya yönelik çok çalışmanın bulunmaması sebebiyle hipotezlere ilişkin yürütülen tartışmalar, farklı kültürlerde yapılmış çalışmaların bulgularına dayandırılarak ele alınmıştır. Özellikle pornografinin içeriksel ve işlevsel boyutlarının ayrıntılı biçimde ve niteliksel olarak ele alınmasıyla Türkiye'de yapılacak ileriki çalışmalar bu noktadaki boşlukların giderilmesinde etkili olacaktır. Pornografiye ilişki algı ve tutumlara dair yapılacak ileriki çalışmaların, üzerinde pek çok yargının olduğu bu konuda muğlak kalan soruların cevaplanmasında önemli bir yere sahip olacağı beklenmektedir.

\section{KAYNAKÇA}

Allen, M., Emmers, T., Gebhardt, L. and Giery, M. A. (1995). Exposure to pornography and acceptance of rape myths, Journal of Communications, 45, 5-26.

Amoah, J. D. (1997). Back on the auction block: A discussion of black women and pornography, National Black Law Journal, 14(2), 203-221.

Bart, P. B. (1985). Pornography: Institutionalizing woman-hating and eroticiszing dominance and submission for fun and profit, Justice Quarterly, 2, 283-292.

Bem, S. L. (1983). Gender schema theory and its implications for child development: raising gender-eschematic children in a gender-schematic society, Journal of Women in Culture and Society, 8(4), 598-616. 
Bridges, A. J. and Morokoff, P. J. (2011). Sexual media use and relational satisfaction in heterosexual couples, Personal Relationships, 18(4), 562-585.

Butler, J. (1997). Excitable Speech: A Politics of the Performative. London: Routledge.

Carroll, J. S., Padilla-Walker, L. M., Nelson, L., J., Olson, C. D., Barry, C. M. and Madesn, S. D. (2008) Generation XXX: Pornography acceptance and use among emerging adults. Journal of Adolescent Research, 23, 6-30.

Çoker, O. (2015). Pornografiye Yönelik Tutumların, Toplumsal Cinsiyet Rolleri ve Demografik Değişkenlerle İlişkisi, Yayınlanmamış Yüksek Lisans Tezi, İstanbul Üniversitesi, İstanbul.

Diamond, I. (1980). Pornography and regression: A reconsideration of "who" and "what". L. Lederer (Ed.), Take back the night (s. 187-203). New York: William Morrow.

Diamond, M. and Dannemiller, J. E. (1989). Pornography and community standards in comparison standards in Hawaii: Comparisons with other states, Archives of Sexual Behaviour, 18(6), 475-495.

Evans-DeCicco, J. A. and Cowan, G. (2001). Attitudes toward pornography and the characteristics attributed to pornography actors, Sex Roles, 44(5-6), 351-361.

Flood, M. and Hamilton, C. (2003). Youth and pornography in Australia: Evidence on the extent of expossure and likely effects, Australia Institute.

Frable, D. E., Johnson, A. E. and Kellman, H. (1997). Seeing masculine men, sexy women, and gender differences: Exposure to pornography and cognitive constructions of gender, Journal of Personality, 65(2), 311-355.

Freud, S. (2014). Uygarlığın huzursuzluğu. İstanbul: Metis Yayınları. (Özgün eser 1930).

Glick, P. and Fiske, S. T. (1996). The ambivalent sexism inventory: Differentiating hostile and benevolent sexism, The Journal of Personality and Social Psychology, 70(3), 491-512.

Glick, P. and Fiske, S. T. (1999). The ambivalence toward men inventory, Psychology of Women Quarterly, 23(3), 519-536.

Griffith, J. D., Hayworth, M., Adams, L. T., Mitchell, S. and Hart, C. (2013). Characteristics of pornography film actors: Self-report versus perceptions of college students, Archives of Sexual Behavior, 42(4), 637-647.

Hald, G. M., Malamuth, N. N., and Lange, T. (2013). Pornography and sexist attitudes among heterosexuals, Journal of Communication, 63(4), 638-660.

Harris, E. A., Thai, M., and Barlow, F. K. (2016). Fifty shades flipped: Effects of reading erotica depicting a sexually dominant woman compared to a sexually dominant man, The Journal of Sex Research, 54(3), 386-397.

Herrman, M. S. and Bordner, D. C. (1983). Attitudes toward pornography in a southern community, Criminology, 21(3), 349-374.

Johansson, T. and Hammarén, N. (2007). Hegemonic masculinity and pornography: Young people's attitudes toward and relations to pornography, The Journal of Men's Studies, 15(1), 57-70.

Kahraman, H. B. (2010). Cinsellik, görsellik ve pornografi (2. bs). İstanbul: Agora Kitaplığı.

Kohut, T., Baer, J. L., and Watts, B. (2016). Is pornography really about "making hate to women"? Pornography users hold more gender egalitarian attitudes than nonusers in a representative American sample, The Journal of Sex Research, 53(1), 1-11. 
Lottes, I., Weinberg, M. and Weller, I. (1993). Reactions to pornography on a college campus: For or against?, Sex Roles, 29(1-2), 69-89.

MacKinnon, C. A. (1987). Feminism unmodified: Discourses on life and law. Harvard university press.

MacKinnon, C. A. and Dworkin, A. (1997). In harms's way: The pornography civil rights hearings. Massachussets: Harvard University Press.

McCormack, T. (1993). If pornography is the theory, is inequality the practice?, Philosophy of the Social Sciences, 23(39), 298-325.

O'Reilly, S., Knox, D. and Zusman, M. E. (2007). College student attitudes toward pornography use, College Student Journal, 41(2), 402.

Parvez, Z. F. (2006). The labor of pleasure how perceptions of emotional labor impact women's enjoyment of pornography, Gender \& Society, 20(5), 605-631.

Perry, S. L. (2017). Does viewing pornography diminish religiosity over time? Evidence from twowave panel data, The Journal of Sex Research, 54(2), 214-226.

Polk, R. K. and Cowan, G. (1996). Perceptıons of female pornography stars, Canadian Journal of Human Sexuality, 5(3), 221-229.

Poulsen, F. O., Busby, D. M. v and e Galovan, A. M. (2013). Pornography use: Who uses it and how it is associated with couple outcomes, Journal of Sex Research, 50(1), 72-83.

Purcell, N. (2012). Violence and the Pornographic Imaginary: The Politics of Sex, Gender and Agression in Hardcore Pornography. New York: Routledge.

Rasmussen, K. R. and Kohut, T. (2019). Does religious attendance moderate the connection between pornography consumption and attitudes toward women?, The Journal of Sex Research, $56(1), 38-49$.

Ritts, V. and Engbretson, R. O. (1991). College students' attitudes toward adult materials and the legal rental of adult videos, College Student Journal, 25(4), 440-450.

Rogala, C. and Tydén, T. (2003). Does pornography influence young women's sexual behavior?, Women's Health Issues, 13(1), 39-43.

Sakallı-Uğurlu, N. (2008). Erkeklere İlişkin Çelişik Duygular Ölçeği'nin Türkçe'ye Uyarlanması, Türk Psikoloji Yazıları, 11 (21), 1-11.

Schneider, J. P. (2000). Effects of cybersex addiction on the family: Results of a survey. Sexual Addiction \& Compulsivity, The Journal of Treatment and Prevention, 7(1-2), 31-58.

Segal, L. (1998). Only the literal: The contradictions of anti-pornography feminism, Sexualities, $1(1), 43-62$.

Sherkat, D. and Ellison, C. (1997). The cognitive structure of moral crusade: Conservative Protestanism and opposition to pornography, Social Forces, 75(3), 957-980.

Shim, J. W., and Paul, B. M. (2014). The role of anonymity in the effects of inadvertent exposure to online pornography among young adult males, Social Behavior and Personality: an international journal, 42(5), 823-834.

Temelli, E. (2019). Romantik ilişkisi olan bireylerde toplumsal cinsiyet rolleri açısından pornografiye yönelik tutumların incelenmesi, Social Mentality and Researcher Thinkers Journal, 5(16), 349-359. 
Tibbetts, S. G. and Blankenship, M. B. (1999). Explaining citizens' attitudes toward pornography: Differential effects of predictors across levels of geographic proximity to outlet sources, Justice Quarterly, 16(4), 735-763.

Wallmyr, G. and Welin, C. (2006). Young people, pornography and sexuality: Sources and attitudes, Journal of School Nursing, 22(5), 290-295.

Watson, L. (2007). Pornography and public reason, Social Theory and Practice, 33(3), 467-488.

Wood, M. M. (2013). Attitudes Toward Pornography Scale. http://mypages.valdosta.edu/mmwood/tampaper.html.

Wu, B. and McCaghy, C. H. (1993). Attitudinal determinants of public opinions toward legalized pornography, Journal of Criminal Justice, 21(1), 13-27.

Zeyneloğlu, S. and Terzioğlu, F. (2011). Development and psychometric properties gender roles attitude scale, Hacettepe Üniversitesi Eğitim Fakültesi Dergisi, 40(40), 409-420. 